\title{
Multiculturalismo e currículo em ação: um estudo de caso*
}

\author{
Ana Canen \\ Universidade Federal do Rio de Janeiro, Faculdade de Educação
}

\section{Angela M. A. de Oliveira}

Universidade Federal Fluminense, Faculdade de Letras

\section{Introdução}

O multiculturalismo, como corpo teórico e campo político, tem sido trazido à tona com intensidade, nos debates atuais. Referindo-se à necessidade de compreender-se a sociedade como constituída de identidades plurais, com base na diversidade de raças, gênero, classe social, padrões culturais e lingüísticos, habilidades e outros marcadores identitários, o multiculturalismo constitui, segundo autores como Semprini (1999) e Grant (2000), uma ruptura epistemológica com o projeto da modernidade, no qual se acreditava na homogeneidade e na evolução "natural" da humanidade rumo a um acúmulo de conhecimentos que levariam à construção universal do progresso. O projeto multicultural, por sua vez, insere-se em uma visão pós-moderna de sociedade, em que a

* Artigo apresentado, em versão preliminar, na $25^{\text {a }}$ Reunião Anual da ANPEd (Caxambu, MG, 29 de setembro a 2 de outubro de 2002). As autoras agradecem à professora Solange de Almeida Cardozo pela contribuição para o desenvolvimento desta pesquisa. diversidade, a descontinuidade e a diferença são percebidas como categorias centrais. Da mesma forma, contrapondo-se à percepção moderna e iluminista da identidade como uma essência, estável e fixa, o multiculturalismo percebe-a como descentrada, múltipla e em processo permanente de construção e reconstrução.

Considerando-se a polissemia do termo multiculturalismo e suas diversas abordagens, é importante salientar que em sua vertente mais crítica, também denominada multiculturalismo crítico ou perspectiva intercultural crítica (Grant, 2000; McLaren, 2000; Canen, 1999, 2001; Canen \& Grant, 1999; Canen \& Moreira, 2001), trata-se de ir além da valorização da diversidade cultural em termos folclóricos ou exóticos, para questionar a própria construção das diferenças e, por conseguinte, dos estereótipos e preconceitos contra aqueles percebidos como "diferentes" no seio de sociedades desiguais e excludentes. No caso da educação e da formação de professores em sociedades multiculturais e desiguais como o Brasil, adotar o multiculturalismo crítico como horizonte norteador significa incorporar, nos discursos curriculares e nas práticas discursivas, desafios a noções que ten- 
dem à essencialização das identidades, entendendoas, ao contrário, como construções, sempre provisórias, contingentes e inacabadas (Silva, 2000; McLaren, 2000; Canen \& Moreira, 2001; Canen, 2001).

Apesar de já caminharmos tendo em vista delinear conceitos teóricos do multiculturalismo crítico, formas de traduzi-lo para o currículo em ação ainda requisitam estudos entre nós, embora já sejam mais freqüentes na literatura anglo-saxônica (Canen, 1999). Já foi realizado, em outro momento, estudo de cunho etnográfico sobre a escola para perceber espaços possíveis de valorização da diversidade cultural (Canen, 2001). Porém, restava acompanhar uma experiência formal de ensino já comprometida, ao menos no âmbito de intenções, com pressupostos do multiculturalismo crítico.

Nesse horizonte de preocupações, o propósito da pesquisa $^{1}$ a que se vincula o presente trabalho era o de levantar categorias centrais para a análise de práticas multiculturalmente comprometidas, bem como identificar experiências pedagógicas imbuídas de uma perspectiva de desafio a preconceitos e desigualdades e que se voltassem a questionamentos sobre a construção das diferenças. Assumíamos que tais experiências poderiam estar dirigindo seu foco a certas dimensões identitárias específicas, tais como raça, etnia, religião, gênero e outras, buscando articular o processo de ensino-aprendizagem a posturas desafiadoras de preconceitos com relação às mesmas. Algumas questões centrais mobilizaram nossa investigação: o que seria uma prática pedagógica multicultural crítica, com base na literatura da área e em uma prática pedagógica imbuída de uma perspectiva voltada

${ }^{1}$ A pesquisa, coordenada por Ana Canen, em desenvolvimento na Faculdade de Educação da Universidade Federal do Rio de Janeiro (UFRJ), com apoio do Conselho Nacional de Desenvolvimento Científico e Tecnológico (CNPq), versa sobre "Multiculturalismo, educação e formação de identidades", visando identificar, entre outros objetivos, experiências multiculturais especificamente voltadas para identidades marginalizadas: negros, homossexuais, indígenas, crianças de rua e outras. ao desafio a preconceitos? Quais seriam seus elementos estruturantes? Que norteadores teóricos poderiam subsidiá-la? Como traduzi-los no currículo em ação? Que potenciais, desafios e questionamentos poderia suscitar com relação ao próprio projeto multicultural?

Para responder a essas questões, em um primeiro momento delineamos a perspectiva teórica da pesquisa, dialogando com autores que têm se debruçado sobre formas de tradução do multiculturalismo em práticas pedagógicas efetivamente comprometidas. Em um segundo momento, realizamos, durante parte do segundo semestre do ano letivo de 2000, um estudo de caso de cunho etnográfico, com a observação sistemática do cotidiano da prática pedagógica de uma professora de ciências, em uma escola municipal na zona norte do Rio de Janeiro, identificada por nós no processo de levantamento de experiências com potenciais multiculturais, no contexto de nosso trabalho de pesquisa referido. Sugerimos que os conceitos de crítica cultural (Boyle-Baise \& Gillette, 1998; Moreira \& Macedo, 2001), hibridização (Bhabha, 1998; McLaren, 2000) e ancoragem social dos discursos (Grant \& Wieczorek, 2000) constituem-se categorias centrais para a construção de caminhos de tradução do multiculturalismo crítico em práticas comprometidas nessa perspectiva. Para efeitos de estruturação do artigo, a discussão dessas categorias será feita no início, ainda que tenham se consolidado, em nosso processo de pesquisa, baseada na confluência entre o diálogo com os autores na linha do multiculturalismo em ação e nos dados do estudo de caso de cunho etnográfico empreendido. Em seguida discutimos a prática pedagógica observada e, ao final, tecemos nossas conclusões e recomendações.

\section{Pensando sobre o multiculturalismo em ação: a prática pedagógica multicultural como prática discursiva e híbrida}

O multiculturalismo tem se tornado "moda", discutido e revisitado em grande parte dos debates atuais. Entretanto, esse tema não pode ser tratado como um 
modismo ou uma "doação" por parte de camadas favorecidas da população: identidades étnicas, raciais, de gênero e outras têm sido sistematicamente caladas em currículos monoculturais, homogeneizadores, com sérias conseqüências para a formação de professores e a educação de futuras gerações (Canen, 1999, 2001; Pinto, 1999; Boyle-Baise \& Gillette, 1998; Grant \& Wieczorek, 2000). Uma dupla dimensão caracteriza a educação multicultural: de um lado, a necessidade de promovermos a equiidade educacional, valorizando as culturas dos alunos e colaborando para a superação do fracasso escolar. Por outro, a quebra de preconceitos contra aqueles percebidos como "diferentes", de modo que se formem futuras gerações nos valores de respeito e apreciação à pluralidade cultural, e de desafio a discursos preconceituosos que constroem as diferenças.

Entretanto, como outros termos na área, o multiculturalismo apresenta uma polissemia (Canen, 1999, 2000, 2001; Canen \& Grant, 1999; Canen \& Moreira, 2001), abarcando posturas epistemologicamente diversas, e mesmo conflitantes. Há os que o concebem apenas como valorização da diversidade cultural, entendida de forma essencializada e folclórica. Nessa perspectiva, o multiculturalismo é reduzido a um "adendo" ao currículo regular, definido como a comemoração de datas especiais, tais como "dia da consciência negra”, "dia do índio" e assim por diante. O fato de o multiculturalismo ser reduzido a essa dimensão tem gerado muitas críticas (Silva, 2000), ressaltando-se a necessidade de discutirem-se seus sentidos mais engajados com posturas teórico-críticas de transformação social (Boyle-Baise \& Gillette, 1998).

De fato, temos argumentado que o chamado multiculturalismo liberal ou de relações humanas, que preconiza a valorização da diversidade cultural sem questionar a construção das diferenças e estereótipos, pouco tem a contribuir para a transformação da sociedade desigual e preconceituosa em que estamos inseridos. Embora o conhecimento de ritos, tradições e formas de pensar de grupos possa, sem dúvida, contribuir para uma valorização da pluralidade cultural e um eventual desafio a preconceitos, essa abordagem, por si só, tende a desconhecer mecanismos históricos, políticos e sociais pelos quais são construídos discursos que reforçam o silenciamento de identidades e a marginalização de grupos. Identificar tais mecanismos e lutar por sua superação passa a ser, justamente, o cerne das preocupações de uma postura multicultural mais crítica, também chamada de perspectiva intercultural crítica, com a qual coadunamos (Canen, 1999, 2001; Canen \& Moreira, 2001; Grant, 2000; McLaren, 2000). Nessa ótica, substitui-se a visão do professor como "conhecedor cultural" por aquela de "trabalhador cultural", ou seja: um agente cultural, que busca transformar relações desiguais e que cruza fronteiras culturais em seus discursos e práticas (Boyle-Baise \& Gillette, 1998).

Tomando-se por base o diálogo com autores que buscam a tradução do multiculturalismo crítico em ações pedagógicas, bem como o estudo de caso de cunho etnográfico empreendido (a ser comentado adiante), três categorias, argumentamos, parecem ser centrais nas práticas pedagógicas multiculturais: crítica cultural, hibridização e ancoragem social dos discursos. Boyle-Baise e Gillette (1998) e Moreira e Macedo (2001) referem-se à crítica cultural permanente dos discursos como a possibilidade dada aos alunos de analisar suas identidades étnicas, criticar mitos sociais que os subjugam, gerar conhecimento baseado na pluralidade de verdades e construir solidariedade em torno dos princípios da liberdade, da prática social e da democracia ativista. Para tal, quatro dimensões da prática pedagógica multicultural são propostas: a construção (que envolve a produção do conhecimento, por parte do aluno, por intermédio de estratégias que o ajudem a buscar, compartilhar e analisar a informação sobre o pluralismo cultural e as desigualdades); voz e escolha (desenvolvimento de atividades democráticas em sala de aula, envolvendo a voz e a escolha dos alunos); crítica (envolvendo estratégias que demandem a discussão de valores culturais conflitantes, críticas ao status quo e investigação das relações culturais de domínio e marginalização); e, por fim, o ativismo social (incentivo a tomadas de posição e ações efetivas, com base nas outras três 
dimensões, que levem ao ganho de habilidades para uma oposição ativa às condições de desigualdade).

A crítica cultural permanente dos discursos implica ressignificar o próprio discurso pedagógico, levando à segunda categoria do presente estudo: a $h i-$ bridização discursiva. Segundo McLaren (2000), a possibilidade de construção de uma linguagem híbri$d a$, ou seja, daquela que cruze as fronteiras culturais, incorporando discursos múltiplos, reconhecendo a pluralidade e a provisoriedade de tais discursos, implica uma reinterpretação das culturas, buscando promover sínteses interculturais criativas. A linguagem híbrida procura superar os congelamentos identitários e as metáforas preconceituosas (tais como a cor preta associada a uma mancha moral e física, ao erro, à negatividade, à morte, à corrupção, ao passo que a branca remeteria à vida e à pureza; provérbios como "o diabo não é tão negro como parece", "hoje é dia de branco", "preto de alma branca", "serviço de branco", "lista negra", "mercado negro", "judiar" etc.), levando a uma "descolonização" dos discursos (Bhabha, 1998). No processo de hibridização, os próprios marcos discursivos dominantes e colonialistas podem ser reapropriados, "traduzidos" em novos referenciais culturais, com base no contato com as culturas plurais. Um exemplo presente na literatura multicultural é o caso de monumentos históricos, que, embora remetam a eventos e "heróis" construídos pelos discursos dominantes de "nação", são reapropriados por grupos culturais marginalizados, e utilizados como pontos de encontro para manifestações de afirmação identitária e requisição de direitos à voz. Compreender a mobilidade das identidades e seu caráter múltiplo, híbrido e transitório implica promover práticas discursivas que contemplem uma linguagem também híbrida, valendo-se de estratégias discursivas que possam ser ressignificadas em sínteses culturais criativas, singulares, locais, móveis e provisórias.

Uma forma interessante de hibridização discursiva é realizada por intermédio de uma estratégia denominada ancoragem social (social mooring), que leva a conexões entre discursos históricos, políticos, sociológicos, culturais e outros (Grant \& Wieczorek,
2000), nas práticas discursivas multiculturais concretas, tendo em vista o alargamento dos quadros de referência pelos quais compreendemos as relações entre conhecimento, pluralidade e poder. Realizar essas conexões significa olhar criticamente para percepções e idéias relativas a conhecimento, educação, formação docente e outras categorias, analisando as presenças e ausências nesses discursos, entendendo-os como intimamente ligados a dinâmicas sociais, culturais e históricas, que passam a ser objeto de discussão. Os referidos autores ilustram a ancoragem social com o tema da biologia referente a doenças, em que o discurso biológico que remete à análise dos vetores das enfermidades vem "ancorado" em discursos sociológicos e históricos. Tais discursos enfatizam aspectos relacionados a desigualdades econômicas e sociais - em última análise, determinantes da maior ocorrência de certas doenças, em segmentos marginalizados da população.

A crítica cultural, a hibridização e a ancoragem social discursiva encontravam-se imbricadas na prática pedagógica, objeto do estudo de cunho etnográfico empreendido, assumindo contornos específicos, a serem analisados a seguir.

\section{O estudo de caso: identificando uma prática pedagógica com potenciais multiculturais}

Conforme comentado anteriormente, o interesse em detectar possíveis caminhos pedagógicos com "potenciais multiculturais" (Canen et al., 2001) le levou-nos a optar por um estudo de caso de cunho etnográfico, em que o acompanhamento sistemático de uma prática pedagógica com tais potenciais poderia ser realizado. Diferentemente de recente trabalho em que um estudo de cunho etnográfico foi realizado em uma escola municipal escolhida ao acaso, de forma

${ }^{2}$ A expressão refere-se à presença de propostas que evidenciam, no que se refere a intenções, preocupações com temas caros ao multiculturalismo, destacando-se a formação identitária e o desafio à construção das diferenças e dos preconceitos. 
que verificasse espaços possíveis de práticas pedagógicas multiculturais (Canen, 2001), no presente estudo o foco era sobre uma prática pedagógica já impregnada por uma perspectiva multicultural crítica (ao menos quanto a intenções). Essa prática foi identificada com base em um levantamento preliminar que realizamos, de experiências com potenciais multiculturais no município do Rio de Janeiro, durante o qual encontramos o nome de uma organização nãogovernamental, o Centro de Articulação de Populações Marginalizadas (CEAP) fundada em 1989, que tem como público alvo a população negra e os setores populares. Entre os principais objetivos da instituição, estão os de contribuir para a formação da consciência crítica para o exercício da cidadania e o combate à discriminação racial e à violência. Uma vez de posse de alguns exemplares do acervo do Centro de Documentação e Pesquisa dessa organização, começamos a analisar o material denominado Cadernos $C E A P$, que propunham, entre outras atividades, jogos com o objetivo de desenvolver, na criança, o discurso argumentativo na luta contra o racismo. Essas atividades, identificadas como parte de um projeto denominado Oficina de Etnociências Seja ético, fale sobre racismo, eram desenvolvidas por uma professora, em uma escola pública, o que fomentou nosso interesse, revelando-se um atalho na nossa jornada de pesquisa em busca de práticas docentes com potenciais multiculturais. $\mathrm{O}$ foco sobre o determinante identitário de raça - conforme sugeria o título da atividade em pauta - poderia fornecer subsídios para pensar-se em potenciais e desafios no privilégio dado a uma dimensão identitária a fim de promover práticas pedagógicas multiculturalmente orientadas.

Após contatos telefônicos com a professora, e com a devida autorização da escola, que abriu suas portas para as pesquisadoras, entrevistas informais foram conduzidas com o propósito de explicar os objetivos da pesquisa, e deu-se início, então, ao estudo de caso de cunho etnográfico planejado. Como instrumento central de estudos de cunho etnográfico, a observação sistemática da prática pedagógica da referida professora, durante um trimestre do ano letivo, permitiu-nos acompanhar um projeto de ciências intitulado "Coisas de pele", desenvolvido por ela em uma turma de 7 série do ensino fundamental, formada, em média, por 35 alunos. As aulas eram de 50 minutos, três vezes por semana, sendo que dois encontros eram no laboratório da escola. A população discente investigada era composta de alunos pertencentes à comunidade do Estácio, que inclui as favelas do Escondidinho, Querosene e Zinco. Cotejamos as observações das aulas com a análise de documentos (planejamentos de curso e de aula, provas, apostilas, material didático) e entrevistas com a professora e alunos, garantindo a triangulação dos dados a fim de conferir maior profundidade à nossa narrativa (AlvesMazzotti \& Gewandsznajder, 1998). Ao final do trabalho de campo, convidamos a referida professora para visitar nosso grupo de pesquisa, na UFRJ, onde ela concedeu uma entrevista coletiva e realizou um workshop, respondendo a perguntas do grupo e apresentando materiais e outros recursos que utilizava. Os dados provenientes da pesquisa empírica serão comentados a seguir.

\section{A prática pedagógica multiculturalmente comprometida: dinâmicas, conteúdos discursivos e tensões}

De que forma a professora de ciências, identificada no contexto de nossa pesquisa, realizava sua prática vinculada a uma perspectiva anti-racista, detectada no discurso do projeto CEAP? Em que medida articulava o conteúdo de ciências com outros discursos de cunho social, cultural e histórico, nessa busca de uma prática pedagógica comprometida com o desafio a preconceitos raciais? Como e em que medida essas características, detectadas mediante a documentação do CEAP a que tivemos acesso, e identificadas como indicativas de potenciais multiculturais, concretizavam-se nos materiais utilizados e nas aulas ministradas? Que percepções e significados eram atribuídos a essa prática pela professora em pauta? Esses questionamentos, oriundos de nossos objetivos de pesquisa sobre práticas pedagógicas multiculturais, 
foram sendo respondidos no decorrer do estudo, fazendo emergir potenciais, desafios e possíveis caminhos na busca da tradução do multiculturalismo para o currículo em ação.

É importante observar, como alertado por McLaren (2000), que o estudo de cunho etnográfico, em uma perspectiva multicultural, não pretende relatar dados com base em uma realidade supostamente apreensível pelo pesquisador. Ao contrário: trata-se de uma narrativa construída baseada no universo cultural e nas opções teóricas e filosóficas do pesquisador, em diálogo com os dados provenientes de sua imersão no campo empírico. Cientes de que tal narrativa representa uma possível (mas certamente não a única) construção discursiva de uma realidade aqui denominada prática pedagógica multicultural, salientamos a necessidade de estarmos atentos às marcas narrativas (Silva, 2000) e aos efeitos de sentido de nossos próprios discursos, desafiando uma cômoda perspectiva de tomá-los como um "retrato fiel" do campo estudado. Assim é que, nessa narrativa, tomando-se por base o impulso pela busca de caminhos plurais para trabalhar-se o multiculturalismo em sala de aula, focalizamos particularmente as formas pelas quais a prática pedagógica acompanhada por nós construía discursivamente as ciências biológicas em busca de efeitos de sentido anti-racistas e multiculturais. É importante destacar que o período do estudo de caso de cunho etnográfico empreendido correspondeu àquele em que o projeto anti-racista, no ensino de ciências estava sendo colocado em prática pela professora, no âmbito do conteúdo referente à pele e a forças. Em que medida tal perspectiva seria estendida ao restante do programa, no decorrer do currículo em ação, restaria para ser verificado em estudos posteriores. Entretanto, apesar de tal limitação, consideramos que as estratégias discursivas desenvolvidas pela professora para efeitos de sentido anti-racista, no decorrer do trimestre acompanhado por nós, poderiam fornecer importantes subsídios para pensar-se em práticas pedagógicas multiculturalmente comprometidas.

Dados das observações indicaram que uma "rotina" de procedimentos era desenvolvida pela profes- sora, que basicamente organizava suas aulas por temas, iniciando-as sempre com base nos conceitos e nas idéias que os alunos possuíam a respeito dos assuntos. Nessa fase, os pontos de vista dos alunos eram valorizados pela professora, após o que ela apresentava um "contraponto" à discussão inicial, que podia ser um roteiro de experimentação, uma música sobre o tema debatido ou um texto de jornal, sintetizando as principais idéias aí apresentadas e preparando os alunos para a próxima fase, ou seja, para o confronto entre as idéias trazidas nesses materiais e aquelas levantadas inicialmente pelos alunos, a propósito do tema em estudo. Tiravam-se, então, algumas conclusões, e a professora partia para uma quarta fase, em que recorria a uma sistematização das idéias e conceitos-chave relacionados ao tema, retomando o texto a ele correspondente no livro didático. A leitura crítica de materiais foi bastante incentivada pela professora, incluindo uma sessão de análise de revista de divulgação científica, na qual os alunos, após preencherem uma ficha previamente elaborada, contendo um roteiro de análise científica, participavam do julgamento crítico da obra lida.

Um exemplo da dinâmica acima relatada pode ser dado mediante o trabalho da professora com o tema "Defesas do corpo". A primeira fase caracterizou-se pelas indagações iniciais feitas à turma, girando em torno do que os alunos entendiam por defesa. Idéias surgiram, tais como defesa é "se preparar para enfrentar inimigos", e assim por diante. Em outro momento, o contraponto a essas idéias foi feito com a exposição do filme brasileiro "Orfeu", em que o negro, a favela, a polícia, a defesa e a morte eram categorias, segundo a professora, "presentes no universo dessas crianças... é a vida deles, há uma identificação total..." (Entrevista com a professora, no decorrer do workshop realizado na universidade em dezembro de 2000). Com base nessas atividades, a professora solicitou que as crianças fizessem desenhos coloridos em cartolina preta, destacando partes do filme que as tivessem marcado (muitos alunos desenharam a polícia subindo o morro, por exemplo). Após essa fase, a professora relacionou a defesa vivenciada pelos alunos em seu contexto cultu- 
ral ao papel de defesa do organismo efetivado pela pele: trouxe algumas informações científicas sobre pigmentos e glândulas, com base no livro didático fornecido pelo Ministério da Educação (MEC) (Ciências - Entendendo a Natureza - Homem no Ambiente - Editora Saraiva, 1998); sistematizou conceitos-chave, utilizando-se também dos mais diferentes materiais de uma minibiblioteca que havia organizado em sala de aula.

O compromisso com a crítica cultural (BoyleBaise \& Gillette, 1998; Moreira \& Macedo, 2001) já podia ser evidenciado mediante a descrição dessa dinâmica, que partia da realidade cultural e social dos alunos para construir o conhecimento biológico, hibridizando discursos da biologia com os da música, do cinema e outros, de forma que problematizasse relações sociais e raciais desiguais. Entretanto, em que medida o "esqueleto" dessa prática pedagógica antes delineada ganhava "sangue" e "carne" em uma perspectiva anti-racista, multicultural? Logo de início, o programa de ciências elaborado pela professora já evidenciava a centralidade do desafio a preconceitos raciais no desenvolvimento de sua prática pedagógica, conforme se percebe nos principais objetivos do curso: "Identificar diferentes práticas que caracterizam culturalmente os diferentes grupos sociais; identificar preconceitos e libertar-se deles; resgatar a identidade pessoal e biológica, de modo a valorizar-se como pessoa humana" (Planejamento do curso de ciências, $7^{\text {a }}$ série). Observa-se, ainda, nestes objetivos, a questão da construção da identidade como fator intimamente associado à prática pedagógica em pauta. Nesse sentido, a "identidade pessoal e biológica" encontravase articulada a um projeto educacional imbuído de uma perspectiva anti-racista, central no multiculturalismo crítico (McLaren, 2000; Canen, 1999, 2001; Canen \& Moreira, 2001; Grant, 2000).

A hibridização de discursos (particularmente por intermédio da ancoragem social) para efeitos de sentido anti-racistas destacou-se, já nesse programa, como uma estratégia crucial na prática pedagógica desenvolvida pela professora. O item "Coisa de pele" pareceu-nos emblemático dessa estratégia. O próprio título revela habilidade no uso da linguagem, já que tal expressão é também associada à atração, à química do amor, subvertendo sentidos e metáforas normatizadas, institucionalizadas, normalmente associando pele a preconceitos raciais. Os objetivos referentes a esse tópico eram: "identificar características e cuidados com a pele; perceber a pele como fator de proteção do corpo; identificar preconceitos e libertar-se deles" (Planejamento de curso de ciências, $7^{\mathrm{a}}$ série). Conforme se verifica, a articulação entre o discurso biológico referente à pele com outro de cunho social, multicultural, referente ao desafio a preconceitos raciais, no âmbito do terceiro objetivo, ilustra a presença da ancoragem social dos discursos (Grant \& Wieczorek, 2000), também presente em atividades de sala de aula propostas pela professora, como, por exemplo, a construção coletiva de um painel intitulado "Mil tons geniais", que remetia não só a tons de pele, mas também a tons musicais. De fato, o enorme painel de cartolina preta apresentava letras de músicas referentes a tons de pele (por exemplo, "Coisa de pele", de Jorge Aragão, e "Black and white", de Michael Jackson), entremeadas por fotos de diferentes personalidades da mídia dotadas dos mais diversos tons de pele. Essas atividades ilustravam a habilidade da professora em lidar com a ambigüidade das palavras, construindo para as mesmas novos efeitos de sentido que superassem associações e metáforas preconceituosas.

Ao mesmo tempo, essa hibridização se fazia acompanhar de uma postura crítica com relação às desigualdades sociais que atingiam os universos culturais daquelas crianças. Uma ilustração interessante foi oferecida na apostila de exercícios, trabalhada em aula, sobre o conceito de força, da física. A introdução à atividade continha a seguinte afirmação: “Antes de discutirmos o conceito de força em Física, vamos pensar juntos sobre força como sinônimo de violência. Usaremos, para nos ajudar, a leitura da música 'Haiti', de Gil e Caetano, e a leitura de jornais e revistas diários do Rio de Janeiro, além de nossos olhos e ouvidos observadores, é claro!" (Apostila elaborada pela professora sobre o tema "Força"). A seguir vinham algumas perguntas, como as seguintes: "Que formas de violência você identifica na música? 
O que é violência para você? Como você justificaria o aumento constante de violência no mundo? Do que você mais tem medo? Você é a favor ou contra a pena de morte? Usando recortes de jornais e revistas, monte um mural sobre Força Física. Quando o herói infantil He-man fala 'Eu tenho a força', ele está correto? Você acha que força física e força em física são conceitos iguais? Por quê?" (idem, ibidem). Mais uma vez, observa-se que a ancoragem social dos discursos, em que conceitos biológicos (ou físicos, como no caso do conceito de força) eram articulados com outros de cunho sociológico (como a questão da violência), a músicas e poesias, e até mesmo a linguagens televisivas (como a do desenho animado "Heman"), consistia na estratégia central da professora. Assim como no exemplo anterior, os sentidos plurais das palavras e conceitos eram trazidos à tona, como na questão da força física e da força em física, subvertendo sentidos únicos, ressignificando-os no contexto dos universos culturais das crianças e da crítica cultural a relações desiguais de poder.

A hibridização por intermédio da ancoragem social discursiva encontrava sua expressão de maior impacto, no nosso entender, quando introduzia, repentinamente, alguma marca representacional (Silva, 2000) na construção da linguagem, que se "chocava" com o discurso biológico, "científico", pretensamente neutro. Um exemplo de como isto ocorria pode ser apresentado com base na prova bimestral por nós analisada, como ilustra a seguinte questão proposta aos alunos: "Explique a diferença banal (grifo nosso) que existe entre peles brancas e pretas." A presença do adjetivo "banal" introduz, "repentinamente", uma "marca discursiva" (idem) que desestabiliza e desafia o processo de construção simbólica da diferença racial, articulando o discurso biológico um discurso social, anti-racista (representado pelo adjetivo aí utilizado). A introdução à referida prova bimestral, bem como outras questões nela presentes, revelam, ainda, a presença marcante da crítica cultural com relação a posturas racistas, como se percebe nos extratos a seguir: "A pele é nosso cartão de apresentação [...], porém, de todos os órgãos, nenhum é veículo de tanto preconceito, tanta discriminação, como a pele [...]" e "[A partir do poema sobre coisas de pele acima], que preconceitos você identifica?" (Introdução contida na prova bimestral de ciências, elaborada pela professora e ministrada à turma durante o segundo semestre de 2000). Conforme se percebe, a hibridização de materiais, linguagens e registros, iluminada pela crítica cultural à construção das diferenças raciais, representou um caminho forte no rompimento de discursos normatizados, "autorizados" e pretensamente "científicos", como a pele e a força, referentes aos temas biológicos e físicos.

Discursos ancorados na poesia e na música, anteriormente comentados, acrescentavam-se a outros ancorados em campos do saber, tais como a antropologia, com interessantes efeitos de sentido anti-racistas. Por exemplo, um texto lido e discutido em aula com a turma ilustra a ancoragem social do discurso biológico ao discurso antropológico, como se observa nas seguintes considerações: "a visão neodarwiniana das raças foi totalmente destruída pelas modernas pesquisas da antropologia. [...] a cor da pele é apenas a manifestação de uma parte ínfima do nosso patrimônio genético ( 8 a 10 genes em algumas dezenas de milhar). [...]. Do mesmo modo que a cor da pele, também muitas outras características [...] não são representativas da diferença inter-racial, por dizerem respeito apenas a alguns genes. É o caso dos grupos sangüíneos. [...] Uma pessoa de grupo sangüíneo $\mathrm{O}$ e outra do grupo A não pertencem a raças distintas, pois não constituem populações diferentes [...]" (Extrato fotocopiado pela professora e distribuído à turma, retirado do livro de L. França e C. Peixinho, $A$ Força do racismo). A partir desse texto, não só parece ficar clara a presença da crítica cultural à construção do preconceito racial, como também se percebe a ancoragem social do discurso biológico ao da antropologia, denunciando a falácia da questão racial, que passa a ser entendida como diferença construída, e não essencializada, aprioristicamente determinada. Assim, o texto desafia a pseudocientificidade do conceito racial, corroborando um efeito de sentido discursivo anti-racista. 
Dessa forma, podemos sugerir que os tópicos do programa de ciências trabalhados no plano do currículo em ação, durante o estudo de caso de cunho etnográfico realizado, exibia uma imbricação de categorias por nós consideradas centrais à prática pedagógica multiculturalmente comprometida (crítica cultural, hibridização e ancoragem social discursiva). Ao mesmo tempo, interessava-nos analisar em que medida a ênfase na categoria racial - identificada inicialmente no projeto de ciências contido na documentação do CEAP e constatado na execução deste projeto no cotidiano da prática pedagógica da professora de ciências acompanhada em nosso estudo - oferecia "aberturas" para o trabalho de desafio à construção das diferenças diversas, ligadas a determinantes outros além dos raciais (tais como gênero, religião, deficiência, padrões lingüísticos e outros).

No entanto, ao mesmo tempo que a questão racial (particularmente referente ao negro) era imbuída de uma perspectiva multicultural crítica, com ênfase em estratégias discursivas de efeito anti-racista, conforme discutido anteriormente, outros determinantes ligados a etnias, linguagens, religião e gênero, quando trazidos à tona, apresentavam tensões entre discursos mais críticos e outros de tom multicultural mais folclórico (Canen, 1999, 2001; Grant, 2000; McLaren, 2000), de valorização da diversidade cultural, porém com pouca ênfase à perspectiva de crítica cultural à construção das diferenças. Por exemplo, no decorrer do período do estudo de caso empreendido, ao finalizar o projeto que abarcou aqueles tópicos do programa trabalhados no âmbito do projeto anti-racista no ensino de ciências, um encontro "de culminância" foi realizado na sala de vídeo da escola municipal acompanhada. Nesse encontro, uma mesa-redonda foi constituída por alunos provenientes de culturas diversas: duas alunas filhas de coreanos, duas alunas de origem indígena (uma do interior do Mato Grosso e a outra recém-chegada do Pará), um aluno que, apesar de carioca, havia vivido muitos anos na Paraíba, tendo chegado de lá há menos de um ano na época do estudo e uma outra que havia tido uma experiência de convivência com cubanos, em Havana, durante um certo período.
A sessão foi iniciada com a exibição de um vídeo sobre cultura afro e sua influência no Brasil, em um tom de multiculturalismo folclórico de valorização da diversidade cultural. Ao final da exibição do vídeo, a professora, de um certo modo, trouxe tal discurso para um tom multicultural mais crítico, na medida em que dava a palavra aos alunos da mesa-redonda para discutirem suas próprias culturas de origem, bem como possíveis choques e/ou discriminações sofridos no ambiente em que se encontravam agora, no Rio de Janeiro. Os alunos convidados, no início, mostravamse um pouco tímidos na narrativa de suas experiências, mas, à medida que iam ganhando confiança, davam seus depoimentos, nos quais a dor do preconceito e a esperança de valorização de suas identidades emergia com força, como ilustramos a seguir:

As pessoas aqui são muito fechadas. Lá (em Belém) elas se comunicavam mais. Você chegava e elas falavam logo... (Tiane, aluna de Belém)

Cuba tem um regime diferente do Brasil. Um lugar superlindo. Ser negro no Brasil é ser diferente de ser negro em Cuba... lá não senti tanto preconceito. (Elisângela, moradora em Cuba por um ano)

Quando cheguei, fui discriminado. As pessoas me achavam diferente por causa do sotaque paraíba. (Hélio, aluno nordestino)

No Mato Grosso a gente tinha muito contato com a natureza. Aprendi a fazer cestos com a minha avó. (Zamê, aluna indígena)

Esses depoimentos configuram aspectos identitários híbridos, relacionados não só à categoria raça, mas também a sotaques, lugares de origem, etnias diversas (como a indígena, por exemplo). Indicam que discursos preconceituosos incidem sobre marcadores identitários plurais (Grant, 2000) e estão imbuídos pelas relações desiguais de poder, em sua gênese. Indicam que aspectos folclóricos, relacionados a padrões culturais distintos (como a cultura de fazer cestos indicada pela aluna indígena), vinham imbricados com aqueles relacionados ao preconceito contra o "outro", percebido como "diferente", ameaçador, requisitan- 
do um olhar sobre a identidade multicultural, para além de marcadores-mestre como raça ou nação, por exemplo. Da mesma forma, superar a homogeneidade dentro de uma categoria identitária (como raça) parecia impor-se, particularmente no discurso da aluna que afirmava que "ser negro no Brasil é diferente de ser negro em Cuba". Tal discurso pode permitir uma visualização da pluralidade de condições identitárias dentro da categoria racial, já apontada por autores como Gilroy (2001), requisitando um olhar que busque superar a essencialização das diferenças, percebendo a pluralidade e a hibridização nas categorias identitárias, como raça.

No entanto, tais tensões e aspectos multiculturais críticos não foram desenvolvidos no debate, trazido mais para o plano do multiculturalismo folclórico, de valorização das culturas e não de desafio à construção das diferenças e dos preconceitos a elas relacionados. Em contrapartida, pode-se argumentar que o espaço aberto para aqueles depoimentos dos alunos, bem como o conteúdo dos mesmos, podem ter sido resultantes da prática pedagógica cotidiana da professora, desafiadora de preconceitos, ainda que focalizando, sobretudo, aqueles ligados particularmente à categoria racial. Ao mesmo tempo, uma outra ordem de considerações refere-se ao fato de o estudo de cunho etnográfico ter sido realizado em um período em que a disciplina direcionava-se ao tópico do programa relacionado à cor de pele. De fato, conforme indicado pela professora no workshop realizado, outras atividades relacionadas a outros aspectos foram trabalhadas, em uma perspectiva de desafio a preconceitos e discriminações, como, por exemplo, atividades relacionadas a preconceitos contra a AIDS e seus portadores. Nesse caso, conforme indicado pela professora no workshop desenvolvido com nosso grupo de pesquisa, uma atividade interessante nessa linha é o jogo "mitos e realidade". O jogo consiste em distribuir cartelas com frases polêmicas, relacionadas a doenças sexualmente transmitidas, de forma que promova o debate sobre tais doenças e desafie discriminações contra portadores de AIDS, indicando dinâmicas à base de estratégias discursivas voltadas ao desafio a preconceitos so- bre outros aspectos identitários além dos de raça, possivelmente no âmbito de outros tópicos do programa de ciências. Também na entrevista concedida na escola, a professora revelou que trabalha com a questão do preconceito contra homossexuais:

Quando falo da reprodução humana, não falo só de heterossexuais. Procuro falar sobre homossexuais. É falar sobre o que o homem está vivenciando, o que a mulher está vivenciando... Como é gostoso ser homem, como é gostoso ser mulher...E também os problemas que acarretam ser homem e ser mulher... (Entrevista realizada em novembro de 2000)

As considerações anteriores permitem-nos sugerir que, com base nos dados da análise documental e nas observações realizadas no estudo de caso de cunho etnográfico empreendido, foi possível identificar uma imbricação das categorias de crítica cultural, hibridização e ancoragem social por nós discutidas no âmbito do currículo em ação da professora em pauta, indicando a presença de uma prática pedagógica no ensino de ciências imbuída de uma perspectiva antiracista - considerada central no multiculturalismo crítico (Grant, 2000; McLaren, 2000; Canen, 1999, 2001; Canen \& Moreira, 2001). Entretanto, impunhase outra ordem de indagações, referentes à gênese e à contextualização daquela prática pedagógica observada. Em outras palavras: Quem era aquela professora? Em que medida as categorias trabalhadas em sua prática pedagógica faziam parte de uma estratégia multicultural crítica consciente? Que potenciais e limitações para se pensar em multiculturalismo crítico, no currículo em ação, apresentava a ênfase na categoria racial naquela prática discursiva analisada? Esses aspectos serão discutidos a seguir.

\section{Discursos e intenções: o que movia o multiculturalismo em ação da experiência observada}

$\mathrm{Na}$ entrevista formal realizada na escola, bem como na fala da professora durante o workshop fei- 
to com nosso grupo de pesquisa na universidade, emergiram elementos das representações que informavam sobre a prática pedagógica realizada por ela. Em primeiro lugar, é importante salientar que a professora possuía forte atuação em movimentos sociais, o que confirma a relevância do diálogo entre instâncias formais de formação inicial e continuada de professores e os movimentos da sociedade civil, particularmente no âmbito de práticas pedagógicas multiculturalmente comprometidas. Um segundo aspecto a ressaltar refere-se às expectativas positivas que a professora nutria com relação à capacidade de aprendizagem de todos os alunos, bem como ao seu envolvimento afetivo no decorrer do processo. De fato, constantemente, no decorrer da entrevista e do workshop realizados, ela referia-se a uma frase de Caetano Veloso - "gente é para brilhar" - para designar as formas pela quais percebia seus alunos e a direção que imprimia a seu trabalho, de modo que os fizessem "brilhar". Esses aspectos não podem ser separados das práticas pedagógicas multiculturalmente comprometidas, confirmando a visão de que a dimensão afetiva deveria impregnar as práticas discursivas nessa perspectiva. É interessante também notar que, ao mesmo tempo em que a prática pedagógica observada era imbuída de sensibilidades multiculturais, com ênfase no desafio a preconceitos ligados à categoria raça, conforme comentado anteriormente, a visão sobre os alunos concretos com que lidava era mais "idealizada" pela professora. De fato, ao ser indagada sobre possíveis preconceitos percebidos nas relações raciais, no âmbito da sala de aula, respondeu que em nenhuma das turmas com que trabalhava notava qualquer tipo de preconceito... Uma terceira ordem de considerações refere-se ao ambiente institucional da escola em que atuava. Embora o aspecto institucional referente ao ethos da escola não tenha sido o foco da pesquisa, é importante salientar que se tratava de uma escola com uma história de compromisso com a luta pelo desafio a preconceitos raciais, traduzida já em seu nome, que homenageava um grande líder negro na luta pelo fim da segregação racial nos Estados Unidos, o que con- firma a relevância de ambientes institucionais na consecução do multiculturalismo crítico, bem como a necessidade de outras pesquisas voltadas para esse aspecto.

Mediante essas considerações, as dimensões centrais da prática observada - construção sobre os universos culturais dos alunos, crítica cultural com base nos elementos extraídos desses universos e hibridização discursiva para efeitos anti-racistas - pareciam ser estratégias intencionais da professora. A valorização dos universos culturais das crianças e a crítica cultural a desigualdades e preconceitos a eles associados perpassava as preocupações com o currículo em ação, conforme expresso pela professora:

Não separo o ambiente onde as crianças vivem de sua cultura. Uma vez tinha que dar uma aula de vertebrados. Naquele dia, a comunidade de Vigário Geral estava sendo morta. E eu ia trabalhar com mamíferos! Então comecei falando como nós, vertebrados mamíferos, nos comportamos diante da violência... Em outra ocasião, o assunto era meio ambiente. Fiz um jogo, o "bolichão". Nesse jogo, eu perguntava: o que devemos derrubar e o que devemos manter para preservar nosso planeta feliz nessa vida? Aí, no quadro negro, eu coloquei o título: "pinos de boliche", e dividi em duas colunas: "derrubar" e "manter". Fui perguntando a eles. Na coluna de "derrubar" surgiram: valão, fogos/balão, cocaína, maconha, queimadas, fumaça de ônibus, violência, armas, sujeira da praia, arrastão, polícia, bandidos, pivetes, corrupção, sprays, doenças... Na coluna de "manter" apareceram: florestas, plantas, praia, animais, escolas!!! (essa ficou!!!), hospitais, camada de ozônio, música, solo, comida, sexo, esperança... Aí, fomos discutindo esses assuntos. [...] Também, quando tinha que falar sobre defesa... as informações científicas estavam ligadas ao ambiente deles, a uma coisa maior que eram as defesas deles. Então eu procurei trabalhar a questão da pele não só com a queratina, a melanina enquanto proteínas químicas, mas aquela melanina daquela pessoa que estava ali, que tem uma pele diferente, com o que ela está sentindo, com o preconceito que ela está vivenciando, com a situação em que ela está. (Depoimento da professora no workshop com o grupo de pesquisa, dezembro de 2000) 
Conforme se observa, elementos que fazem parte dos universos daquelas crianças, vivendo muitas vezes em condições limite em termos de carências socioeconômicas e no bojo da violência, do tráfico de drogas e dos conflitos entre polícia e bandidos, eram trazidos para as discussões e relacionados ao tópico da biologia a ser trabalhado em aula, mediante uma estratégia consciente da professora. A crítica cultural, com ênfase na estratégia de dar "voz e vez aos alunos" (Boyle-Baise \& Gillette, 1998), configurava-se como opção deliberada, informando a prática pedagógica analisada, buscando uma análise crítica de formas de transformação social, como ilustrada no "jogo do bolichão", anteriormente citado. A hibridização de linguagens e materiais (McLaren, 2000; Canen \& Grant, 1999; Canen \& Moreira, 2001), observada em sala de aula, traduzia-se também no discurso da professora, que muitas vezes ressignificava discursos curriculares das próprias políticas educacionais, a princípio não centralizados em questões multiculturais críticas, mas que eram reapropriados por ela em uma perspectiva multicultural, como no exemplo a seguir:

Os conteúdos, até algum tempo atrás, eram muito fechadinhos... Mesmo com o advento dos PCN [Parâmetros Curriculares Nacionais], isso não mudou muito. Mas, apesar disso, já dá para você não adulterar o conteúdo, mas você selecionar, priorizar aqueles conteúdos que dariam para você fazer uma ligação mais ampla com a sociedade... As próprias diretrizes dos PCN do Ensino Médio falam nisso, falam em três coisas: política de igualdade, estética da sensibilidade e ética da identidade. Eu procuro ver jeitos de transpor isso para a sala de aula... por exemplo, a música do Chico, "Meu Guri", e outras que eu uso (gosto muito de músicas), isto faz parte da estética da sensibilidade do MEC. Também, quando faço jogos, tem a ver com a identidade deles... Eu trabalho com a Biologia que tenha significado para eles... (Entrevista com a professora, novembro de 2000)

Dessa forma, como se percebe, a hibridização de discursos oficiais com estratégias discursivas permeadas pelo multiculturalismo revela sentidos e traduções possíveis daqueles discursos pelo professor multiculturalmente orientado (Canen, 2000; Moreira \& Macedo, 2001). Isso parece indicar, com clareza, que a hibridização de discursos pode representar um caminho alternativo para práticas pedagógicas que se pretendam transformadoras, ainda que construídas no quadro de políticas curriculares centralizadoras, em um movimento de ressignificação de seus discursos à luz de um projeto multicultural crítico.

Ao mesmo tempo, é importante salientar que a estratégia de ancoragem social dos discursos (Grant \& Wieczorek, 2000), empreendida por intermédio de elementos discursivos que se "chocavam" com efeitos de sentido já "normatizados" baseados na construção de significados racistas (conforme comentado na sessão anterior, referente aos dados das observações), era uma estratégia consciente, intencional, percebida no depoimento da professora:

Gosto de desafiar os alunos. Peço muitas vezes para eles discutirem frases do tipo: "As vavas larvais copavam o varal do roco zulal". O que quer dizer isto? Qual o sentido desta frase? Ela tem uma sintaxe. A lógica sintática tem sujeito, predicado - e aí, quando tem isto, já se pensa que há sentido! Se alguém fala uma porção de bobagens em um discurso, mas com a lógica sintática, já engana a todos! As palavras "vavas larvais" não existem! Na verdade, essa frase não existe! Não significa nada! Nessa atividade, eu faço as perguntas: Quem copava o varal do roco zulal? O que faziam as larvas? E aí mostro que não faz sentido. Quem é? Que faziam as larvas? A escola tem esse discurso. O que significa isto? Não significa nada! A escola tem essa visão, essa posição. Mas a gente tem que mudar. Tem que mostrar que não quer dizer nada. Não se pode aceitar tudo, só porque faz sentido a sintaxe. Isso é que eu tento, quando uso essas frases. Aí, relaciono com outras em Ciências. Para fazer pensar... (Entrevista com a professora, em 7 de dezembro de 2000)

Isso indica que as próprias marcas da construção da diferenciação racial, eram desafiadas em sua gênese - a construção do discurso. Pode-se argumentar, com base nas ilustrações da prática pedagógica acom- 
panhada e dos depoimentos anteriormente transcritos, que a ancoragem social dos discursos, realizada por marcas discursivas que rompem a pseudocientificidade e a pseudoneutralidade dos discursos curriculares (no caso em pauta, do discurso biológico), representou um ponto forte de uma prática multiculturalmente comprometida, na medida em que questionava a construção das diferenças e dos preconceitos a ela associados, em sua gênese - os próprios discursos. Acima de tudo, as estratégias discursivas antes analisadas eram movidas, conforme se percebe, diante dos dados das observações e dos depoimentos, por um compromisso multicultural de rompimento de preconceitos, de crítica cultural, de construção de identidades multiculturalmente comprometidas, questionadoras das injustiças e das desigualdades, indicando que o projeto multicultural crítico é possível no âmbito do currículo em ação.

\section{Conclusões}

O presente estudo buscou articular considerações teóricas sobre o multiculturalismo com a análise de formas concretas traduzidas no currículo em ação. Partindo da necessidade de levantarem-se categorias de análise que ajudassem a delinear elementos norteadores de práticas pedagógicas multiculturalmente comprometidas, foram realizados uma análise de literatura na área, bem como um estudo de caso de cunho etnográfico, focalizando a atuação de uma professora de ciências comprometida com uma perspectiva anti-racista no ensino daquela disciplina, identificada durante nossa pesquisa sobre experiências multiculturais no ensino formal.

Diante da confluência entre as idéias veiculadas pelos autores que se debruçavam sobre o multiculturalismo em ação, bem como da prática pedagógica observada, argumentamos que as categorias de crítica cultural, hibridização e ancoragem social discursiva foram centrais para os efeitos de discurso anti-racistas buscados. Ao construir sua prática pedagógica baseada nos universos culturais dos alunos, hibridizando o discurso biológico com outros provenientes de campos diversos como a antropologia, a música e a poesia, a professora acompanhada por nós produzia ressignificações da linguagem, subvertendo sentidos anti-racistas e trabalhando o multiculturalismo crítico (particularmente centralizado na questão racial) no nível da gênese discursiva da construção das diferenças.

No entanto, privilegiar um marcador identitário específico (no caso, raça), pode apresentar potenciais e limitações para o multiculturalismo em ação. $\mathrm{Na}$ prática pedagógica acompanhada por nós, observouse que outros determinantes tais como gênero, linguagem e etnia, quando surgiam, eram revestidos de um discurso mais folclórico, contrastando com o tom multicultural crítico de desafio a preconceitos que predominou no tratamento à categoria racial. É importante salientar, entretanto, que o discurso da professora pareceu indicar que aqueles aspectos também seriam tratados, no decorrer do programa, em uma perspectiva desafiadora da construção discursiva das diferenças. Além do mais, o fato de que crianças falavam abertamente sobre preconceitos sofridos à base de padrões identitários percebidos como "diferentes" (como ocorreu durante a sessão de culminância do projeto sobre pele) pode ser interpretado como diretamente relacionado às estratégias discursivas desenvolvidas pela professora para desafiar o racismo, no decorrer de suas aulas de ciências, o que poderia indicar o potencial do trabalho como uma categoria identitária (como raça) para o multiculturalismo em ação. Entretanto, outras pesquisas seriam necessárias, para que se percebesse em que medida tal ênfase não recairia em uma "hierarquização das diferenças”, em que certos marcadores identitários são percebidos de forma essencializada, congelada, em detrimento de posturas que buscam compreender as identidades como híbridas, multifacetadas e em permanente construção.

Perceber a prática pedagógica multicultural como uma prática que se constrói discursivamente, por causa de intenções voltadas ao desafio à construção das diferenças e dos preconceitos a ela relacionados, parece ser um caminho central para a concepção de uma 
formação de professores multiculturalmente comprometidos. Em tempos de choques culturais e intolerância crescente quanto àqueles percebidos como "diferentes", a educação e a formação de professores não podem mais se omitir quanto à questão multicultural. Narrar nossas experiências, dialogar com movimentos sociais e com práticas efetivadas nessa linha, bem como incrementar nossas pesquisas sobre pedagogias multiculturalmente comprometidas são, sem dúvida, alguns caminhos promissores para a concretização do ideal multicultural no currículo em ação.

ANA CANEN, doutora em educação pelo Department of Education da University of Glasgow, é professora adjunta da Faculdade de Educação e pesquisadora do Programa de Estudos e Documentação "Educação e Sociedade", da Universidade Federal do Rio de Janeiro e do CNPq. Desenvolve pesquisa em Multiculturalismo e Formação de Professores. Possui diversas publicações em periódicos nacionais e internacionais. É autora do livro Avaliação da aprendizagem em sociedades multiculturais (Editora Papel e Virtual, 2001). Com Antonio Flavio Barbosa Moreira, organizou o livro Ênfases e omissões no currículo (Papirus Editora, 2001).E-mail: acanen@domain.com.br

ANGELA MARIA ARAUJO DE OLIVEIRA, graduada em letras pela UFRJ, é mestranda na Faculdade de Letras da Universidade Federal Fluminense. Seu interesse de pesquisa é em Multiculturalismo e Linguagem. E-mail: angelao@alternex.com.br

\section{Referências bibliográficas}

ALVES-MAZZOTTI, A., GEWANDSZNAJDER, F., (1998). $O$ método nas ciências naturais e sociais: pesquisa quantitativa e qualitativa. São Paulo: Pioneira.

BHABHA, H. K., (1998). O local da cultura. Belo Horizonte: Editora da UFMG.

BOYLE-BAISE, M., GILLETTE, M., (1998). Multicultural education from a pedagogical perspective: a response to radical critiques. Interchange, v. $29, \mathrm{n}^{\circ} 1$, p. 17-32.

CANEN, A., (2000). Educação multicultural, identidade nacional e pluralidade cultural: tensões e implicações curriculares. $\mathrm{Ca}$ dernos de Pesquisa, n. 111, p. 135-150.
, (1999). Multiculturalismo e formação docente: experiências narradas. Educação e Realidade, v. 24, n² 2, p. 89-102. (2001). Universos culturais e representações docentes: subsídios para a formação de professores para a diversidade cultural. Educação e Sociedade, nº 77, p. 207-227.

CANEN, A., GRANT, N., (1999). Intercultural perspective and knowledge for equity in the Mercosul countries: limits and potentials in educational policies. Comparative Education, v. $35, n^{\circ} 3$, p. $319-330$.

CANEN, A., MOREIRA, A. F. B., (2001). Reflexões sobre o multiculturalismo na escola e na formação docente. In: (orgs.). Ênfases e omissões no currículo. São Paulo: Papirus. p. $15-43$.

CANEN, A., ARBACHE, A. P., FRANCO, M., (2001). Pesquisando multiculturalismo e educação: o que dizem as dissertações e teses. Educação e Realidade, v. 26, nº 1, p. 161-181.

GILROY, P., (2001). O Atlântico negro. Rio de Janeiro: Editora 34.

GRANT, N., (2000). Multicultural education in Scotland. Edinburgh: Dunedin Academic Press.

GRANT, C. A., WIECZOREK, K., (2000). Teacher education and knowledge in the "knowledge society": the need for social moorings in our multicultural schools. Teachers College Record, v. 102, n 5, p. 913-935.

McLAREN, P., (2000). Multiculturalismo revolucionário: pedagogia do dissenso para o novo milênio. Porto Alegre: Artes Médicas.

MOREIRA, A. F. B., MACEDO, E. F., (2001). Em defesa de uma orientação cultural na formação de professores. In: CANEN, A., MOREIRA, A. F. B. (orgs.). Ênfases e omissões no currículo. São Paulo: Papirus. p. 117-146.

PINTO, R. P., (1999). Diferenças étnico-raciais e formação do professor. Cadernos de Pesquisa, no 108, p. 199-232.

SEMPRINI, A., (1999). Multiculturalismo. São Paulo: EDUSC.

SILVA, T. T., (2000). A produção social da identidade e da diferença. In: SILVA, T. T. da (org.). Identidade e diferença: a perspectiva dos estudos culturais. Petrópolis: Vozes. p. 73-102.

Recebido em agosto de 2002 Aprovado em outubro de 2002 
Ana Canen e Angela M. A. de Oliveira Multiculturalismo e currículo em ação: um estudo de caso

O multiculturalismo, campo teórico e político voltado para a valorização da pluralidade cultural e para o desafio à construção das diferenças, tem adquirido visibilidade crescente no campo educacional. Tendo em vista a incrementar a produção do conhecimento sobre possíveis formas de tradução do projeto multicultural para o currículo em ação, o presente estudo objetivou responder à seguinte questão central: o que seria uma prática pedagógica multicultural crítica? Para tal, analisa criticamente dados provenientes de um estudo de caso de cunho etnográfico, focalizando uma prática pedagógica identificada como portadora de "potenciais multiculturais". Sugere, a partir da confluência entre teoria e empiria, categorias centrais para o currículo em ação multiculturalmente comprometido.

Palavras-chave: multiculturalismo, currículo em ação, pluralidade cultural.

Multiculturalism and curriculum in action: a case study

Multiculturalism, a theoretical and political field aimed at valuing cultural diversity and challenging the construction of differences, has been gaining increasing visibility within the educational arena. Based on that approach, the present paper aims to contribute to the production of knowledge related to possible ways of translating the multicultural project into the curriculum in action. It seeks to answer the following central question: what is a critical multicultural pedagogical practice? In order to do so, it analyses data from an ethnographic case study that focused on a pedagogical practice informed by "multicultural potentials". From the articulation between theory and empirical evidence, the paper advances in the presentation of categories deemed crucial for a multiculturally oriented curriculum in action.

Key-words: multiculturalism, curriculum in action, cultural plurality.

Maria Onete Lopes Ferreira

A crise dos paradigmas e o marxismo entre os pesquisadores em trabalho $\mathrm{e}$ educação em universidades brasileiras

Tomando como problema a crise na qual mergulharam as teorias do conhecimento na atualidade, reflete sobre as conseqüências de tal momento de fragilidade teórica no campo da pesquisa educacional, especialmente entre os estudiosos que tratam de objetos referentes à relação "Trabalho e Educação". As fontes eleitas foram as teses produzidas nos Programas de Pós-Graduação em Educação das universidades PUC/SP, USP, UNICAMP, UFRJ e UFRGS, entre os anos de 1994 e 1998. O critério definidor do intervalo está amparado no fato de que, seguramente, a partir daquele momento inicial seria possível contemplar a problemática da crise dos referenciais, e que este intervalo deveria fechar-se no instante em que tivesse início o trabalho de campo. A questão norteadora da investigação teve como eixo o nível de compromisso dos pesquisadores com as teorias historicistas, em especial o marxismo, assim como com aquelas ditas pós-modernas. O resultado do trabalho demonstra ampla predominância do referencial marxista entre os pesquisadores investigados.

Palavras-chave: crise dos referenciais, marxismo, pós-moderno.

The crisis of paradigms and Marxism amongst educators Examines the consequences for educational research of the crisis in which the theories of knowledge are actually immersed. It especially examines research whose authors take as object of investigation themes concerning the relationship between work and education, since these themes are common objects of research in Post-graduate Programmes in Education in Brazil. Theses produced at PUC/SP, USP, UNICAMP, UFRJ and UFRGS, between 1994 and 1998, were examined. The period of research was determined by the year in which the crisis in social science investigation was first detected in Brazil, and the year in which this study was initiated. The aim of the investigation was to examine the nature of the research commitment to historical theories, especially Marxism, as well as to the so-called post-modern theories. The result of the investigation shows an ample predominance of Marxist theoretical frameworks among the researchers studied.

Key-words: crisis of theoretical frameworks, marxism, post-modern.

Solange Jobim e Souza e Nilton Gamba Jr.

\section{A escolarização como um projeto de} civilização

$\mathrm{O}$ artigo discute as contribuições de Michel Foucault e Norbert Elias para a historiografia da educação e para a história da escolarização. Especificamente, desenvolve, a partir de Norbert Elias, uma reflexão sobre o significado da monopolização do ensino elementar pelo Estado, no século XIX e nas sociedades ocidentais, enquanto estratégia fundamental para completar o projeto de civilização.

Palavras-chave: escolarização, civilização, Estado.

Schooling as a project of civilisation This paper focuses on the ideas of Michel Foucault and Norbert Elias and their ascendancy in the studies of the history of education and schooling. Based on Elias's studies, it has the purpose of analysing the relationship 